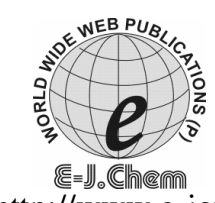

http://www.e-journals.net

ISSN: 0973-4945; CODEN ECJHAO

E-Journal of Chemistry

2011, 8(4), 1993-1999

\title{
Synthesis and Structural Studies of Some Inorganic Polymers of Succinoyl Carboxymethyl Cellulose
}

\author{
H.D.JUNEJA", MANISHA JOSHI ${ }^{*}$ and N.T.KHATI \\ "Department of Chemistry \\ R T M Nagpur University, Nagpur - 440033, India \\ *Department of Chemistry \\ Priyadarshini College of Engineering, Nagpur- 440019, India \\ Department of Chemistry \\ Priyadarshini College of Engineering, Nagpur- 440019, India \\ manisha_pcea@yahoo.co.in
}

Received 17 January 2011; Accepted 1 March 2011

\begin{abstract}
The inorganic polymers containing transition metals such as $\mathrm{Mn}$ (II), $\mathrm{Co}(\mathrm{II})$, $\mathrm{Ni}(\mathrm{II}), \mathrm{Cu}$ (II) and $\mathrm{Zn}$ (II) were synthesized by using succinoyl carboxymethyl cellulose (SCMC) in aqueous media. The newly synthesized polymers were characterized by elemental analysis, IR spectroscopy, TG analysis, UV reflectance spectra and magnetic moment. On the basis of these studies, the composition of the polymeric unit was found to be [M(II)L]n, [M'(II)L. $\left.2 \mathrm{H}_{2} \mathrm{O}\right] \mathrm{n},\left\{\left[\mathrm{M}\right.\right.$ '(II)L. $\left.\left.2 \mathrm{H}_{2} \mathrm{O}\right] n \mathrm{H}_{2} \mathrm{O}\right\}$, where $\mathrm{M}=\mathrm{Zn}$ (II), $\mathrm{M}^{\prime}=\mathrm{Mn}(\mathrm{II}), \mathrm{Ni}(\mathrm{II})$ and $\mathrm{Cu}(\mathrm{II})$ and $\mathrm{M}^{\prime}=\mathrm{Co}(\mathrm{II}), \mathrm{L}=\mathrm{SCMC}$ ligand. On the basis of instrumental techniques, it has been found that the $[\mathrm{Zn}(\mathrm{II})(\mathrm{SCMC})] \mathrm{n}$ inorganic polymer has tetrahedral geometry, whereas $\left\{[\mathrm{Cu}(\mathrm{II})(\mathrm{SCMC})] \cdot 2 \mathrm{H}_{2} \mathrm{O}\right\} \mathrm{n}$ has square planar geometry and $\left.\left[\mathrm{Mn}(\mathrm{III})(\mathrm{SCMC}) \cdot 2 \mathrm{H}_{2} \mathrm{O}\right] \mathrm{n},\left\{\left[\mathrm{Co}(\mathrm{II})(\mathrm{SCMC}) \cdot 2 \mathrm{H}_{2} \mathrm{O}\right)\right] \cdot \mathrm{H}_{2} \mathrm{O}\right\} \mathrm{n}$ and $[\mathrm{Ni}$ (II) (SCMC). $\left.2 \mathrm{H}_{2} \mathrm{O}\right] \mathrm{n}$ have octahedral geometry. The decomposition temperatures of the inorganic polymers have been determined by TGA. The TGA reveal that the Mn(II) polymer of SCMC is highly thermally stable than rest of the polymers and these polymers can be used as thermal resisting materials.
\end{abstract}

Keywords: Carboxymethyl cellulose, SCMC, TGA, Thermal degradation

\section{Introduction}

Cellulose derivatives have gained acceptance for pharmaceutical, cosmetic, food, adhesives, textiles and packaging uses. They must be non-toxic, noncarcinogenic, biocompatible and in no way injurious in the biological environment. Cellulose ether is the most widely used cellulose derivative in food and pharmaceutical industries. They are obtained by replacing the hydroxyl groups with either alkyl or hydroxy-alkyl groups. Accordingly, a wide range of cellulose ethers are manufactured to meet specific needs of industrial applications ${ }^{1}$. This is the case with sodium carboxymethylcellulose (Na-CMC), an anionic linear cellulose ether. $\mathrm{CMC}$ presents the structure of 
a polyanion consisting of repeating units of anhydroglucose residues, substituted by sodium carboxymethyl groups. Cellulose derivatives such as carboxymethylcellulose (CMC) and hydroxypropylcellulose are biocompatible ${ }^{2}$ and have been applied in drug delivery formulations ${ }^{3-6}$ and as components of therapies for preventing post surgical adhesions (e.g., Genzyme's Seprafilm) $)^{7-11}$. A number of papers have been published on the uses of chelating exchanges for trace element preconcentration from various matrix using cellulose as solids sorbents for the separation of the transition metals in analyses such as: GFAAS spectrometry, ICP-MS for reduction and aggregation of silver, copper and cadmium ions in aqueous solutions of gelatin and CMC and with dichromate for separation of copper-lead in secondary copper minerals ${ }^{12-15}$. A paper in the literature outlined the importance of biopolymers as remediation agents in wastewater treatment ${ }^{16}$.

The present work is a part of systematic investigation undertaken in the laboratory which includes the synthesis of thermally stable inorganic polymers, the mechanism of their formation and their structural aspects. The metal ions selected for the present work belongs to 3-d block transition elements viz. $\mathrm{Mn}(\mathrm{II}), \mathrm{Co}(\mathrm{II}), \mathrm{Ni}(\mathrm{II}), \mathrm{Cu}(\mathrm{II})$ and $\mathrm{Zn}(\mathrm{II})$.

\section{Experimental}

All the chemicals used as starting materials in the synthesis of ligand and its inorganic polymers were of extra pure quality. Sodium carboxymethyl cellulose (E.Merck, Germany), succinic acid (E.Merck, Germany). manganous acetate, cobaltous acetate, nickel acetate (E.Merck, Germany), cuprous acetate and zinc acetate (S.D.Fine Chem., India).

\section{Instruments}

Microanalysis of C, H, N were carried out on EAS superuser elemental analyser system $\mathrm{GmbH}$, access: VarioEL superuser, NEERI. Infrared spectra in the region $4000-400 \mathrm{~cm}^{-1}$ were recorded in the solid state (KBr Pallets) in pharmacy department, RTMNU, Nagpur, using FTIR - 101A Shimadzu. The kinetics of thermal decomposition was investigated by using non-isothermal manual thermal analyzer at Department of Chemistry, Rashtrasant Tukadoji Maharaj Nagpur University, Nagpur. The heating rate employed was $10^{\circ} \mathrm{C} / \mathrm{min}$ and the mass loss was recorded continuously. Magnetic susceptibility of inorganic polymers was determined by Gouy's method at room temperature using mercury tetrathiocyanatocobaltate(II) as standard.

\section{Synthesis of ligands}

The ligand is synthesized by triturating the mixture of $10 \mathrm{~g}$ of finely powdered Na salt of CMC (low viscosity) and $30 \mathrm{~mL}$ of glycerol with mortar and pestle. The triturated mixture is added in small amounts into the vertex of $0.2 \mathrm{M}$ aqueous succinic acid solution and stirred electrically until a clear gel was formed. The synthesized ligand was stored in an airtight wide mouth bottle.

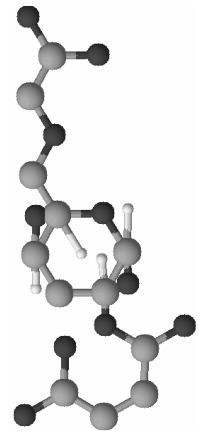

Figure 1. Succinoyl carboxymethyl cellulose (SCMC) ligand 


\section{Synthesis of inorganic polymers}

The inorganic polymers in the present work have been synthesized by refluxing $10 \mathrm{~g}$ of SCMC ligand and $100 \mathrm{~mL}$ of $0.2 \mathrm{M}$ aqueous metal acetate at $100{ }^{\circ} \mathrm{C}$ in an oil bath for $2 \mathrm{~h}$. The inorganic polymers obtained were then cooled, filtered and washed with hot water to remove any metal acetate and unreacted ligand.
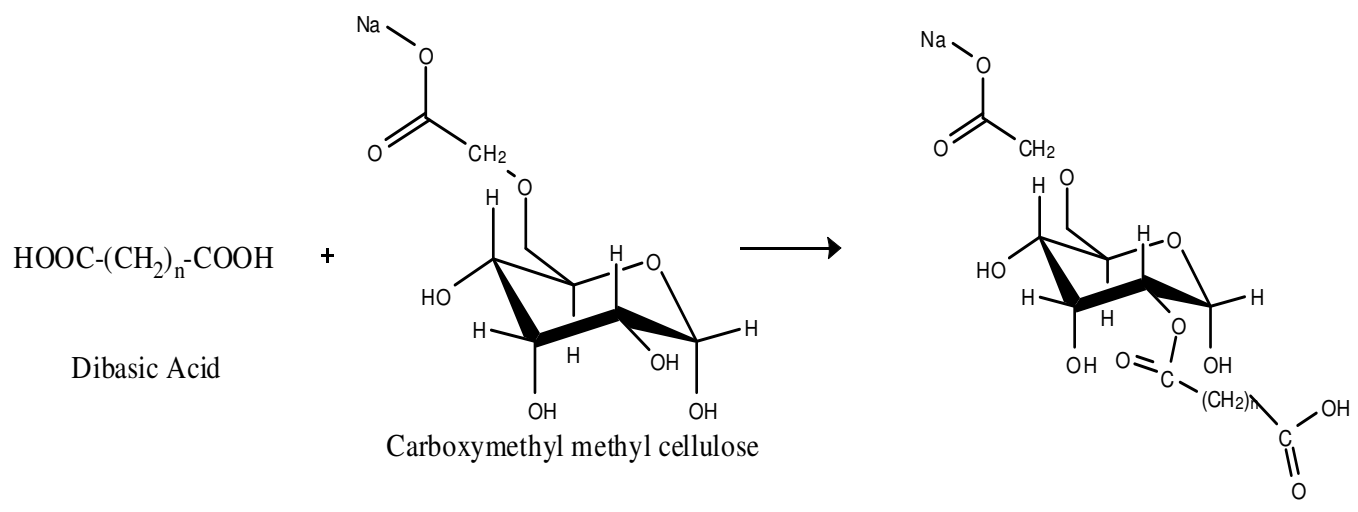

CMC Dibasic acid ligand

Figure 2. Synthesis of succinoyl CMC ligand $n=2$ for succinic acid

\section{Results and Discussion}

\section{Composition of the polymeric unit}

The composition of the polymeric unit was assigned on the basis of elemental analysis. The presence of water of crystallization was ascertained on the basis of thermal studies. The Composition of polymeric unit was found to be [M(II)L]n, [M'(II)L.2 $\left.\mathrm{H}_{2} \mathrm{O}\right] \mathrm{n}$, $\left\{\left[\mathrm{M}^{\prime}\right.\right.$ '(II) $\left.\left.\mathrm{L} .2 \mathrm{H}_{2} \mathrm{O}\right] \mathrm{H}_{2} \mathrm{O}\right\}$, where $\mathrm{M}=\mathrm{Zn}(\mathrm{II}), \mathrm{M}^{\prime}=\mathrm{Mn}(\mathrm{II}), \mathrm{Ni}(\mathrm{II})$ and $\mathrm{Cu}(\mathrm{II})$ and $\mathrm{M}^{\prime}$ ' $=\mathrm{Co}(\mathrm{II}), \mathrm{L}=\mathrm{SCMC}$ ligand. On the basis of elemental analysis, infrared spectra, reflectance spectra, magnetic measurements and thermal studies, the proposed structure of these inorganic polymers shown in Figures 5 and 6 . The elemental analysis of ligand and polymers is given in Table 1.

Table 1. Elemental analysis of succinoyl carboxymethyl cellulose (SCMC) \& its inorganic polymers

\begin{tabular}{|c|c|c|c|c|c|c|c|c|}
\hline \multirow{2}{*}{ Inorganic Polymer } & \multirow{2}{*}{$\begin{array}{l}\text { Empirical } \\
\text { Formula }\end{array}$} & \multirow{2}{*}{ 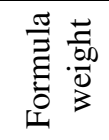 } & \multicolumn{2}{|c|}{$\% \mathrm{C}$} & \multicolumn{2}{|c|}{$\% \mathrm{H}$} & \multicolumn{2}{|c|}{$\% \mathrm{M}$} \\
\hline & & & Calcd & Found & Calcd & Found & Calcd & Found \\
\hline SCMC & & 319 & & & & & -- & -1 \\
\hline $\begin{array}{c}{[\mathrm{Mn}(\mathrm{II})(\mathrm{SCMC})} \\
\left.\left(\mathrm{H}_{2} \mathrm{O}\right)_{2}\right]_{\mathrm{n}}\end{array}$ & $\mathrm{MnC}_{12} \mathrm{H}_{19} \mathrm{O}_{12}$ & 410.01 & 35.12 & 36.29 & 4.63 & 5.64 & 13.39 & 13.26 \\
\hline $\begin{array}{c}\{[\mathrm{Co}(\mathrm{II})(\mathrm{SCMC}) \\
\left.\left.\left(\mathrm{H}_{2} \mathrm{O}\right)_{2}\right]\left(\mathrm{H}_{2} \mathrm{O}\right)\right\}_{\mathrm{n}}\end{array}$ & $\mathrm{CoC}_{12} \mathrm{H}_{21} \mathrm{O}_{13}$ & 432.01 & 33.30 & 32.28 & 4.39 & 5.06 & 13.64 & 13.08 \\
\hline $\begin{array}{c}{[\mathrm{Ni}(\mathrm{II})(\mathrm{SCMC})} \\
\left.\left(\mathrm{H}_{2} \mathrm{O}\right)_{2}\right]_{\mathrm{n}}\end{array}$ & $\mathrm{NiC}_{12} \mathrm{H}_{19} \mathrm{O}_{12}$ & 413.77 & 34.80 & 33.20 & 4.59 & 4.87 & 14.18 & 14.54 \\
\hline $\begin{array}{c}\{[\mathrm{Cu}(\mathrm{II})(\mathrm{SCMC})] \\
\left.\left(\mathrm{H}_{2} \mathrm{O}\right)_{2}\right\}_{\mathrm{n}}\end{array}$ & $\mathrm{CuC}_{12} \mathrm{H}_{19} \mathrm{O}_{12}$ & 418.62 & 34.40 & 33.70 & 4.50 & 4.80 & 15.17 & 15.90 \\
\hline$[\mathrm{Zn}(\mathrm{II})(\mathrm{SCMC})]_{\mathrm{n}}$ & $\mathrm{ZnC}_{12} \mathrm{H}_{15} \mathrm{O}_{10}$ & 384.38 & 37.46 & 36.67 & 3.90 & 3.50 & 17.00 & 17.26 \\
\hline
\end{tabular}




\section{Infrared spectral studies}

The IR spectral data for SCMC and its inorganic polymers with $\mathrm{Mn}(\mathrm{II}), \mathrm{Co}(\mathrm{II}), \mathrm{Ni}(\mathrm{II}), \mathrm{Cu}(\mathrm{II})$ and $\mathrm{Zn}(\mathrm{II})$ are given in Table 2. Characteristic peak of functional groups was observed in the IR Spectra of SCMC: $-\mathrm{OH}$ group at $3400 \mathrm{~cm}^{-1}$, $-\mathrm{CH}$ group at $2927 \mathrm{~cm}^{-1}, \mathrm{C}=\mathrm{O}$ group of nonconjugated ketones, carbonyls and in ester groups at $1718 \mathrm{~cm}^{-117,18},-\mathrm{COOH}$ group at $1655 \mathrm{~cm}^{-1}$. The IR spectra of polymers show few new weak absorption bands in the range of 600 to $670 \mathrm{~cm}^{-1}$ which may be assigned to the M-O (Metal-Oxygen) bonds ${ }^{19}$. The weak band observed around $780-900 \mathrm{~cm}^{-1}$ may be assigned to coordinated water molecule. The infrared spectral assignments of ligand and inorganic polymers are tabulated in Table 2.

Table 2. IR spectral assignments of SCMC ligand and its inorganic polymers

\begin{tabular}{ccccccc}
\hline Assignment & SCMC & Mn(II) & Co(II) & Ni(II) & Cu(II) & Zn(II) \\
\hline O-H & 3400 & 3450 & 3400 & 3440 & 3441 & 3500 \\
C-H & 2927 & 2928 & 2924 & 2920 & 2920 & 2910 \\
C=O & 1718 & 1718 & 1718 & 1718 & 1718 & 1718 \\
COOH & 1655 & 1655 & 1655 & 1620 & 1560 & 1637 \\
COO- & 1458 & 1458 & 1458 & 1458 & 1508 & 1458 \\
C-O - & 1043 & 1115 & 1050 & 1055 & 985 & 1066 \\
H-O-H & - & 898 & 900 & 781 & - & - \\
Coordinated & - & 600 & 600 & 669 & 596 & 660 \\
M-O & - & & & & & \\
\hline
\end{tabular}

Magnetic moment and electronic spectral studies of SCMC inorganic polymers

The magnetic moment values of SCMC inorganic polymers are given in Table 3 . These magnetic moment values support the octahedral geometry for $\mathrm{Mn}(\mathrm{II}), \mathrm{Co}(\mathrm{II})$ and $\mathrm{Ni}(\mathrm{II})$ inorganic polymers $^{20}$ and the tetrahedral geometry for $\mathrm{Cu}(\mathrm{II})$ polymers. Since $[\mathrm{Zn}(\mathrm{II})(\mathrm{SCMC})]_{\mathrm{n}}$ is a d10 system and hence is diamagnetic in nature, however, on the basis of elemental analysis, infrared spectra and thermal decomposition data, its most probable geometry is suggested to be tetrahedral.

Table 3. Magnetic moment data of SCMC inorganic polymers

\begin{tabular}{cccccc}
\hline $\begin{array}{c}\text { Inorganic } \\
\text { polymer }\end{array}$ & $\begin{array}{c}\text { Gram Sus- } \\
\text { ceptibility } \\
\chi \text { g X 10 } \\
\text { (CGS Unit) }\end{array}$ & $\begin{array}{c}\text { Atomic } \\
\text { susceptibility } \\
\chi \text { A X 10 } \\
\text { (CGS Unit) }\end{array}$ & $\begin{array}{c}\text { Corrected } \\
\text { atomic suscep- } \\
\text { tibility } \\
\chi \text { A X 10 } \\
\text { (CGS Unit) }\end{array}$ & $\begin{array}{c}\text { Effective } \\
\text { magnetic } \\
\text { moment } \\
\text { B.M. }\end{array}$ & $\begin{array}{c}\text { Stereo - } \\
\text { chemistry }\end{array}$ \\
\hline Mn-SCMC & 36.28 & 14.87 & 14.99 & 5.93 & Octahedral \\
Co-SCMC & 21.45 & 9.26 & 9.38 & 4.69 & Octahedral \\
Ni-SCMC & 12.74 & 5.27 & 5.39 & 3.55 & Octahedral \\
Cu-SCMC & 3.30 & 1.38 & 1.50 & 1.87 & Tetrahedral \\
\hline
\end{tabular}

Electronic spectral properties include the electronic transitions which take place between the ground levels of coordination clusters and the excited levels. The spectra of the coordination compounds may be classified into ligand field bands and charge transfer bands. The ligand field bands are essentially concerned with the transition between different $d$-orbital which results from the application of the ligand field. Electronic spectral assignments of SCMC inorganic polymers are given in Table 4. 
Table 4. Electronic spectral assignments of SCMC inorganic polymers

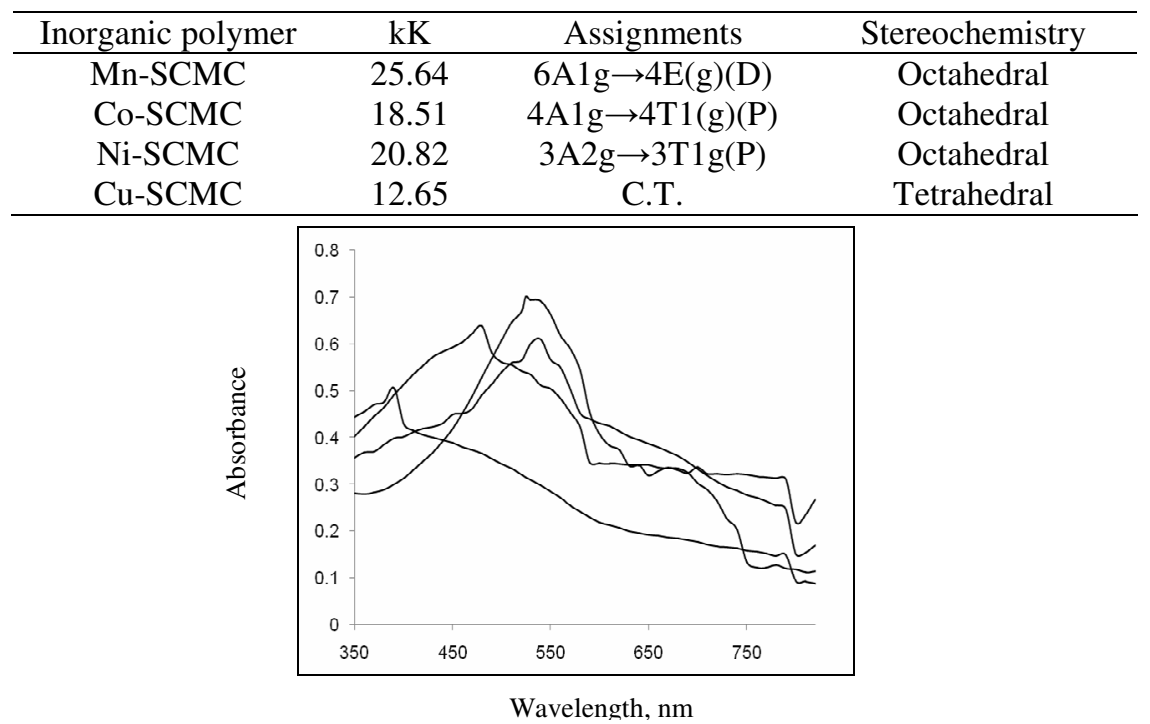

Figure 3. Electronic spectra of SCMC inorganic polymers

\section{Thermogravimetric analysis of SCMC inorganic polymers}

The mass loss of SCMC inorganic polymers at various temperatures have been shown in Figure 4. TG curve of $\mathrm{Mn}(\mathrm{II})(\mathrm{SCMC})$ polymer shows no mass loss up to $140{ }^{\circ} \mathrm{C}$ giving an indication of absence of water of crystallization. It shows mass loss of $8.7 \%$ between $140-240{ }^{\circ} \mathrm{C}$ due to the loss of two coordinated water molecules. It then shows a gradual decrease from $280{ }^{\circ} \mathrm{C}$ up to $540{ }^{\circ} \mathrm{C}$ which may be due to decomposition of the ligand attached to the metal ion, hereafter no further mass loss was observed due to the formation of stable metal oxide. The decomposition temperature was found to be $380{ }^{\circ} \mathrm{C}$.

TG curve of $\mathrm{Co}(\mathrm{II})(\mathrm{SCMC})$ polymer shows presence of lattice water as there is $3.72 \%$ mass loss was observed between $100-120{ }^{\circ} \mathrm{C}$. It shows mass loss of $7.68 \%$ between $120-210{ }^{\circ} \mathrm{C}$ due to the loss of two coordinated water molecules. After $260{ }^{\circ} \mathrm{C}$ it shows gradual decrease in mass up to $500{ }^{\circ} \mathrm{C}$ which may be due to decomposition of the organic species attached to the metal ion; after $500{ }^{\circ} \mathrm{C}$ no further mass loss was observed, may be due to the formation of stable metal oxide. The decomposition temperature was found to be $350{ }^{\circ} \mathrm{C}$.

In TG curve of $\mathrm{Ni}(\mathrm{II})(\mathrm{SCMC})$ polymer, no mass loss is observed up to $150{ }^{\circ} \mathrm{C}$ giving an indication of absence of water of crystallization in the polymer. It shows mass loss of $8.41 \%$ between $150-220^{\circ} \mathrm{C}$ due to the removal of two coordinated water molecules. It then shows a gradual mass loss from $250{ }^{\circ} \mathrm{C}$ up to $560{ }^{\circ} \mathrm{C}$ which may be due to decomposition of the ligand which is attached to the metal ion. Hereafter no further mass loss was observed indicating the formation of stable metal oxide. The decomposition temperature was found to be $350{ }^{\circ} \mathrm{C}$.

$\mathrm{The} \mathrm{Cu}(\mathrm{II})(\mathrm{SCMC})$ inorganic polymer shows presence of two lattice water as there is $8.5 \%$ mass loss was observed between $100-140{ }^{\circ} \mathrm{C}$. This polymer shows absence of coordinated water, since no mass loss was observed between $140-200{ }^{\circ} \mathrm{C}$, after $200{ }^{0} \mathrm{C}$ gradual decrease in mass up to $520{ }^{\circ} \mathrm{C}$ was observed which may be due to the decomposition of the ligand attached to the metal ion hereafter no further mass loss was observed due to the formation of stable metal oxide. The decomposition temperature was found to be $360{ }^{\circ} \mathrm{C}$. 
TG curve of $\mathrm{Zn}(\mathrm{II})$ (SCMC) shows no mass loss up to $240{ }^{\circ} \mathrm{C}$ indicating absence of lattice and/or coordinated water in the polymer. It then shows a gradual decrease up to $580{ }^{\circ} \mathrm{C}$ which may be due to the decomposition of the ligand attached to the metal ion; after which formation of stable metal oxide takes place. The decomposition temperature was found to be $330{ }^{\circ} \mathrm{C}$. The Thermoanalytical data of these inorganic polymers have been reported in Table 5 .

Table 5. Thermoanalytical data of SCMC inorganic polymers

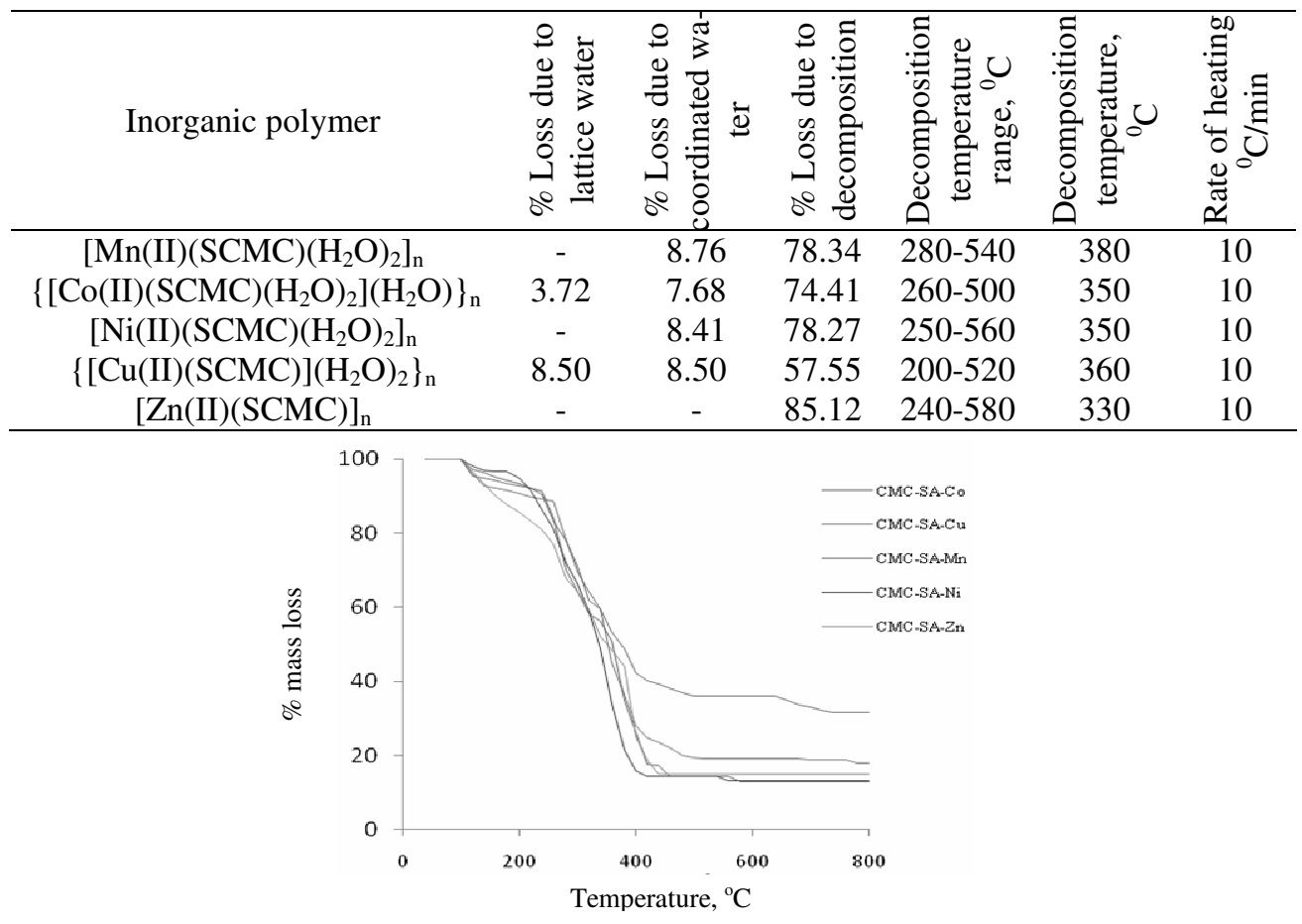

Figure 4. Thermogram of SCMC-M inorganic polymers

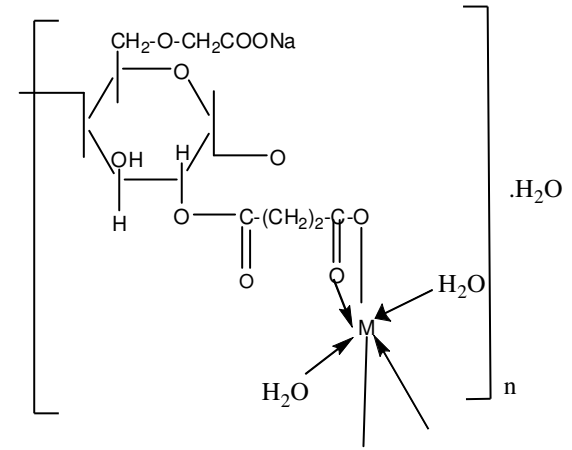

Figure 5. Proposed structure of six coordinated inorganic polymers

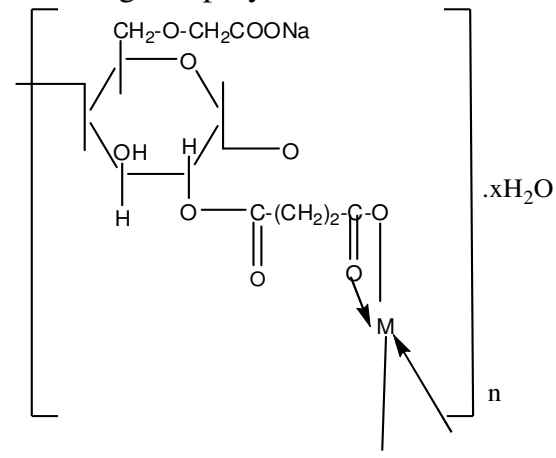

Figure 6. Proposed structure of four coordinated inorganic polymers

\section{Conclusion}

On the basis of elemental analysis, infrared spectra, reflectance spectra, magnetic moment data and thermal studies, the $\left\{[\mathrm{Cu}(\mathrm{II})(\mathrm{SCMC})]\left(\mathrm{H}_{2} \mathrm{O}\right)_{2}\right\} \mathrm{n}$ and $[\mathrm{Zn}(\mathrm{II})(\mathrm{SCMC})] \mathrm{n}$ inorganic polymers 
have tetrahedral geometry, whereas $\left[\mathrm{Mn}(\mathrm{II})(\mathrm{SCMC})\left(\mathrm{H}_{2} \mathrm{O}\right)_{2}\right] \mathrm{n},\left\{\left[\mathrm{Co}(\mathrm{II})(\mathrm{SCMC})\left(\mathrm{H}_{2} \mathrm{O}\right)_{2}\right]\left(\mathrm{H}_{2} \mathrm{O}\right)\right\} \mathrm{n}$ and $\left[\mathrm{Ni}(\mathrm{II})(\mathrm{SCMC})\left(\mathrm{H}_{2} \mathrm{O}\right)_{2}\right] \mathrm{n}$ inorganic polymers are octahedral in nature. On the basis of thermal degradation studies, $\left[\mathrm{Mn}(\mathrm{II})(\mathrm{SCMC})\left(\mathrm{H}_{2} \mathrm{O}\right)_{2}\right] \mathrm{n}$ has been found to be highly thermally stable than rest of the polymers reported in this paper. Since these inorganic polymers are highly thermally stable and form films, therefore, they can be used as thermally stable coating material.

\section{Acknowledgment}

Authors are thankful to the Head, Department of Chemistry; Rashtrasant Tukadoji Maharaj Nagpur University, Nagpur, India, for providing necessary facilities to carry out the work.

\section{References}

1. Ana Paula Franco and Ana Lucia Ramalho Merce, Reactive Functional Polymers, 2006, 66, 667-681.

2. Miyamoto T, Takahashi S, Ito H, Inagaki H and Noishiki Y, J Biomed Mater Res., 1989, 23, 125-133.

3. Barbucci R, Leone G and Vecchiullo A, J Biomater Sci Polym Ed., 2004, 15, 607-619.

4. Pal K, Banthia A K and Majumdar D K, Biomed Mater., 2006, 1(2), 85-91.

5. Rodriguez R, Alvarez-Lorenzo C and Concheiro A, J Control Release, 2003, 86, 253-265.

6. Tas C, Ozkan Y, Savaser A and Baykara T, Farmaco, 2003, 58(8), 605-611.

7. Ito T, Yeo Y, Highley C B, Bellas E, Benitez C A and Kohane D S, Biomaterials, 2007, 28, 975-983.

8. Leach R E, Burns J W, Dawe E J, SmithBarbour M D and Diamond M P, Fertil Steril., 1998, 69, 415-418.

9. Lee J H, Nho Y C, Lim Y M and Son T I, J Appl Polym Sci., 2005, 96, 1138-1145.

10. Liu L S and Berg R A, J Biomed Mater Res., 2002, 63, 326-332.

11. Tate M C, Shear D A, Hoffman S W, Stein D G and LaPlaca M C, Biomaterials, 2001, 22(10), 1113-1123.

12. Lii C, Tomasik P, Zaleska H, Liaw S and Lai V M F, Carbohydr Polym., 2002, 50(1), 19-26.

13. Bulatovic S, Wysouzil D M and Bermejo F C, Minerals Eng., 2001, 14(11), 1483-1491.

14. Zih-Perenyi K, Laszticity A, Horvath Z and Levai A, Talanta, 1998, 47, 673.

15. Kapoor S and Gopinathan C, Rad Phys Chem., 1998, 53, 165-170.

16. Houghton J I and Quarmby J, Curr Oppin Biotechnol., 1999, 10, 259.

17. Owen N L and Thomas D W, Appl Spectroscopy, 1989, 43, 451-455.

18. Hergert H L and Sarkanen K V, Ludwig (Eds.) C H, Wiley, New York, 1971, 267-297.

19. Nakamoto K, John Wiley, New York, 1970, 270.

20. Figgis B N and Lewis, J Prog Inorg Chem., 1964, 6, 27. 


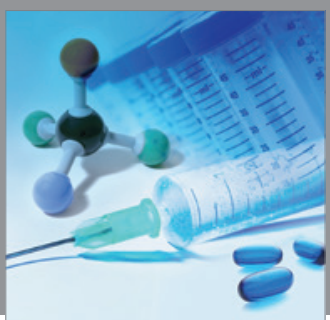

International Journal of

Medicinal Chemistry

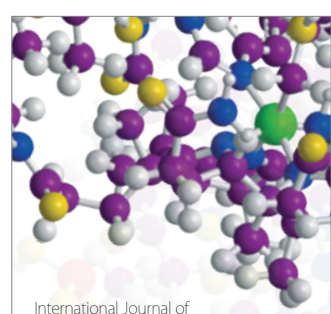

Carbohydrate Chemistry

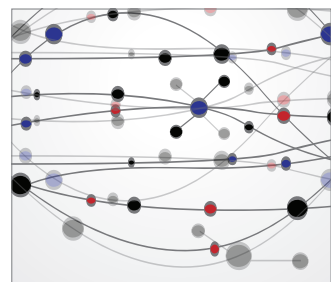

The Scientific World Journal
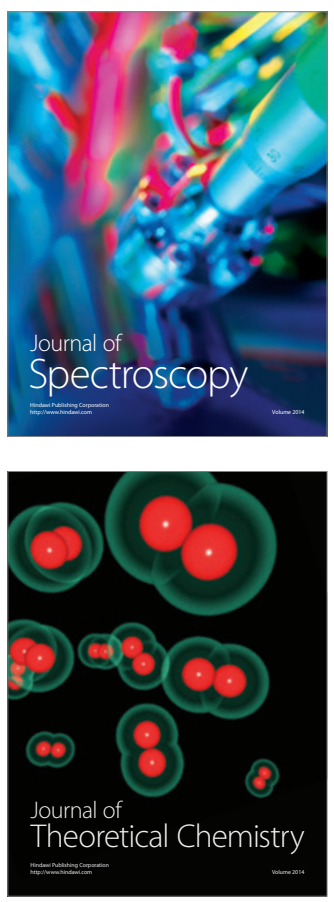
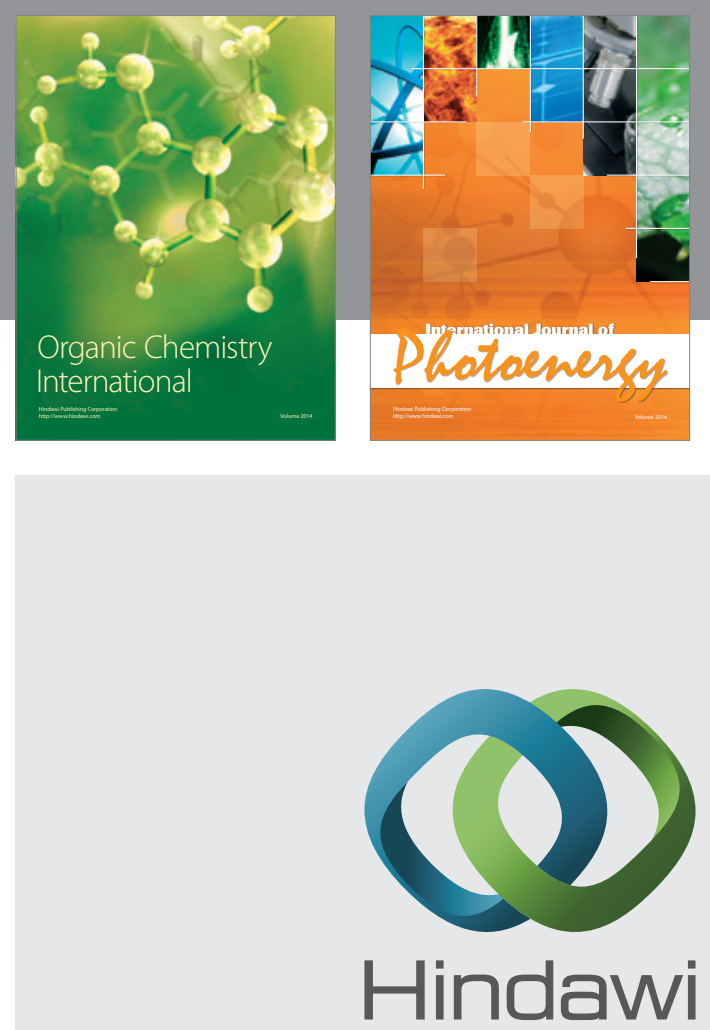

Submit your manuscripts at

http://www.hindawi.com
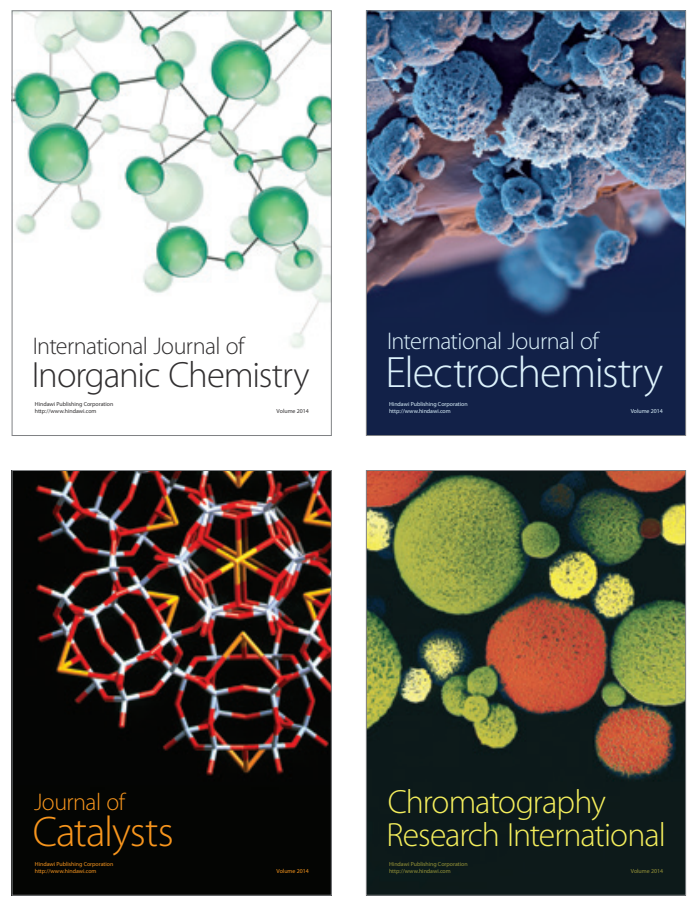
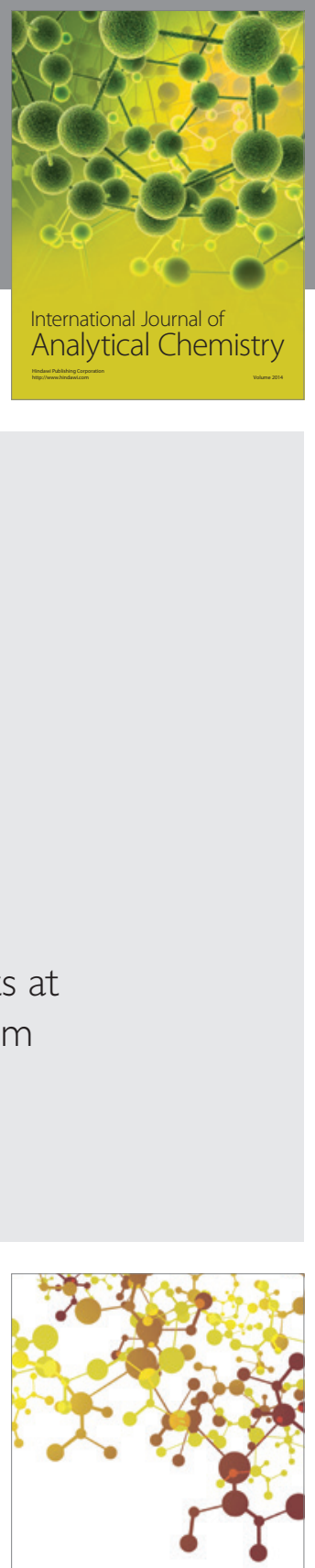

Journal of

Applied Chemistry
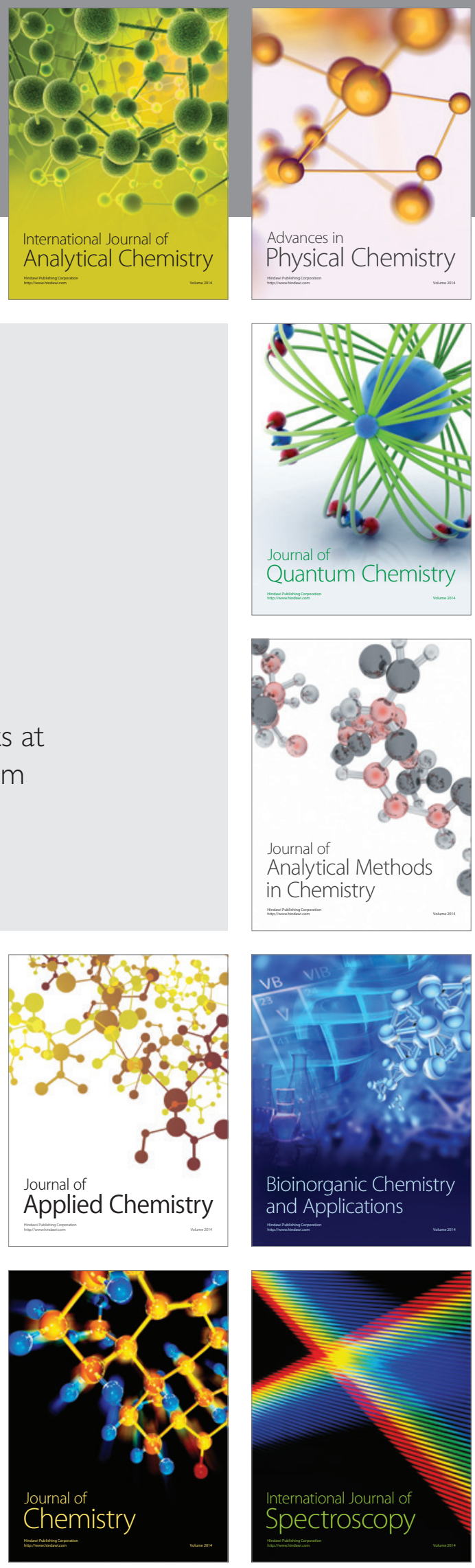